\title{
ASPECTOS DO BACHARELISMO EM MACHADO DE ASSIS
}

\section{BACHELORISM FEATURES IN MACHADO DE ASSIS'S WORK}

\begin{abstract}
JOSÉLIA BATISTA MENDES
Graduada em Licenciatura em Letras, com Habilitação em Português, pela Universidade Castelo Branco (RJ); Especialista em Português, pelas Faculdades Promove (MG); foi Professora de Literatura da Escola Estadual "Coronel Aristides Batista", e atualmente leciona na Escola Estadual São Francisco, ambas em Ibiaí (MG). joseliavicmendes@hotmail.com

YURY VIEIRA TUPYNAMBÁ DE LÉLIS MENDES

Estudante do Quarto Ano da Faculdade de Direito da Universidade Estadual de Montes Claros, onde é Monitor Concursado das Disciplinas "Teoria Geral do Estado/Ciência Política" (Profa Aurenice da Mota Teixeira) e "Direito Constitucional I" (Prof. Érik Rodrigues da Silva); é Trainee da Economontes (Empresa Júnior de Economia da Unimontes), sob coordenação da Prof ${ }^{a}$ Elbe Figueiredo Brandão Santiago; Conselheiro do Conselho de Ensino, Pesquisa e Extensão (CEPEX) da Unimontes, onde também integra sua Câmara de Pesquisa.
\end{abstract} yuryvmendes@hotmail.com

\section{RESUMO}

Este trabalho, de forma interdisciplinar, visa a estudar dimensões do bacharelismo presentes na obra machadiana. Assim, utilizaremos do método histórico para entendermos o bacharel em Direito na obra machadiana bem como sua imagem no século XIX e sua importância para a formação do Estado Nacional Brasileiro. Para tanto, inicialmente, aborda-se este último processo, e, a posteriori, a formação do Bacharel em Direito como componente da Elite desse Estado. Além disso, analisa-se o arquétipo do personagem bacharelesco machadiano, e correlacionase a ficção com o momento histórico em que se inseriam autor e obra, desfazendo-se, assim, a imagem apolítica que muito se atribuiu a Machado de Assis. Em seguida, analisam-se algumas personagens machadianas, verificando-se a estereotipização do bacharel em Direito brasileiro. Por fim, conclui-se a necessidade desta figura na literatura machadiana, como ente da Elite sócio-político-cultural de nossa nação, em seu primeiro século como Estado Soberano.

\begin{abstract}
These papers aim to study the dimensions of the bachelorism present in Machado's work. Then, we will use historical method to understand the Bachelor of Laws in Machado's work, as well as the figure of such bachelor in the $19^{\text {th }}$ century, and its importance for the generation of the Brazilian National State. For such purpose, this latter process is described at first and, after, the formation of the image of the Bachelor of Laws as Brazilian Elite is discussed. Moreover, the archetype of Machado's bachelor character is analysed, and a link between fiction and the historical context is established, undoing the apolitical trait that was long attributed to Machado de Assis. Furthermore, some of Machado's characters are studied, confirming the stereotype about the Brazilian Bachelor of Laws. At last, it is concluded that the presence of such figure in Machado's work, as a member of the socialpolitical-cultural Elite of the Brazilian nation during its first century as a Sovereign State.
\end{abstract}

Keywords: Bachelor of Laws; Law, History and Literature, Machado de Assis.
Palavras-chave: Bacharel em Direito; Direito História e Literatura; Machado de Assis.

\section{SUMÁRIO}

INTRODUÇAO; 1 BREVES APONTAMENTOS SOBRE O BACHARELISMO NO BRASIL; 2 PERSONAGENS MACHADIANOS E BACHARELISMO: UMA ANÁLISE; 2.1 Romances: Primeira Fase; 2.2 Romances Maduros; CONCLUSÃO; REFERÊNCIAS. 


\section{INTRODUÇÃO}

No século XIX, não se pode deixar de notar a predominância dos bacharéis de Direito na vida social, política e cultural brasileira. A esse fenômeno social chama-se bacharelismo.

Para Afonso Arinos De Melo Franco, entretanto, há distinção entre bacharelismo (postura do advogado) e jurisdicismo (atitude do jurista). Para o escritor da obra de memórias "A alma do tempo", ao primeiro fenômeno associa-se a atividade política; já ao segundo, associa-se a produção teórico-filosófica. ${ }^{1}$ Para Venâncio Filho, distinguem-se: o bacharel (homem de cultura, dado às letras, mas que não exerceria a profissão), do advogado (homem prático, dado à política e à - aplicação da - lei), do jurista (teóricofilósofo, apolítico, dado mais ao Direito do que à lei). ${ }^{2}$

(...) a herança luso-coimbrã favoreceu o desenvolvimento de uma intelectualidade jurídica constituída por juristas e bacharéis. 0 "juridicismo" estaria associado a posturas teóricas, à abstração filosófica e científica, à inadequação com a política militante e a maior capacidade indutiva, apta a extrair e criar o Direito a partir da dinâmica social, "sempre aberta às mudanças, às inovações da realidade vital, seja na direção evolutiva (como Tobias), seja na orientação reacionária (como Campos)". Já o "Bacharelismo", por natureza, expressaria um pendor para questões não especulativas, mais afeito à mecânica exegética, estilística e interpretativa, resultando no apego às "fórmulas consagradas, à imutabilidade das estruturas", aos padrões prefixados e aos valores identificados com a conservação. ${ }^{3}$

Soma-se, ainda, um outro significado ao termo bacharelismo (HOUAISS, 2001), conforme elenca Laíse Helena Barbosa Araújo, "pelo qual se traduz a linguagem marcada pela ornamentação verborrágica e vacuidade de sentidos". ${ }^{4}$

Este trabalho, através de uma perspectiva interdisciplinar, visa estudar dimensões do bacharelismo presentes na obra machadiana.

\footnotetext{
${ }^{1}$ Afonso Arinos de Melo Franco apud VENÂNCIO FILHO, Alberto. Das Arcadas ao bacharelismo. p. 291-292 [apud KOZIMA, José Wanderley. Instituições, Retórica e o Bacharelismo no Brasil. In: WOLKMER, Antônio Carlos (Org.). Fundamentos de História do Direito. Belo Horizonte: Del Rey, 1996, p. 227-246].

In:

http: / / www.academia.org.br/abl/cgi/cgilua.exe/sys/start.htm?infoid=63\&sid=258

${ }^{3}$ WOLKMER, Antonio Carlos. História do Direito no Brasil. $7^{\mathrm{a}}$ ed. Rio de Janeiro: Forense, 2014, p. 106.

${ }^{4}$ ARAÚJO, Laíse Helena Barbosa. O Medalhão do Século XIX: o bacharelismo em Machado de Assis. (Monografia, CESUPA, Belém-PA, 2008).
} 
Assim, utilizaremos de pesquisa bibliográfica para delinearmos uma visão acerca do bacharel em Direito, como subsídio a análises histórico-literárias do objeto em questão, de modo a entendermos a presença do mesmo na obra machadiana, e no contexto ao qual estão inseridos o autor e obra. Outrossim, o método histórico será utilizado para, a partir do qual se traçar uma análise acerca (da visão) do bacharel de Direito no século XIX, e sua importância para a formação do Estado Nacional Brasileiro.

Para tanto, procura-se, de início, demonstrar como se deu a construção do Estado Nacional Brasileiro, e, ademais, a formação do Bacharel em Direito como a Elite que o compôs. Procura-se, ainda, adentrando-se ao mundo da crítica literária machadiana, analisar o arquétipo do personagem bacharelesco na obra machadiana, bem como correlacionar a realidade da ficção com o momento histórico ao qual estavam inseridos o autor e obra, anseiando, assim, se desfazer a imagem apolítica e distanciada que por muito tempo se atribuiu a Machado de Assis.

Em seguida, analisa-se algumas personagens machadianas, verificando-se a tendência da estereotipização do bacharel em Direito brasileiro. Por fim, conclui-se a necessidade da presença do bacharel em Direito na literatura machadiana, como ente da Elite sócio-políticocultural de nossa nação, em seu primeiro século de existência como Estado Soberano.

\section{BREVES APONTAMENTOS SOBRE O BACHARELISMO NO BRASIL}

As origens do bacharelismo deitam suas raízes em Portugal: é que recorrente era a significativa participação de juristas nos Conselhos da Coroa desde o alvorecer do Estado português. $^{5}$

Os bacharéis de Direito no Brasil, desde os egressos de Coimbra, sempre desempenharam um importante papel sócio-político-cultural no cenário nacional. Leciona o jurista mineiro, o Ministro Adauto Lúcio Cardoso (apud FIUZA, 2010):

Relançai os olhos pela História deste País. Desde os egressos de Coimbra que a intolerante justiça Del Rei degredava para a jovem Colônia, até os dias de hoje, vereis o quanto deve o Brasil ser grato aos seus bacharéis. Eles estiveram na formação da consciência nacional, nas insurreições nativas do Centro, do Nordeste e do Sul; estiveram presentes na Independência, atuantes na Abolição, militantes na propaganda da República, insubmissos no Estado Novo (p.44-45).

5 "Obra de juristas foi a justificação da posse do trono ao mestre de Avis, cabendo também a eles delimitar as fronteiras entre os bens do príncipe e a coisa pública, com forte no direito romano" (KOZIMA, 1996, p. 240). 
Para se poder entender a importância dos bacharéis em Direito, e o "perigo" que os mesmos poderiam apresentar aos interesses "metropolitanos" da Coroa Portuguesa, no Período Colonial, justamente por se constituírem a parcela letrada e politizada dos cidadãos do Império português (e portanto sempre nocivos à manutenção do status quo absolutista), Américo Lacombe $^{6}$ reproduz o parecer contrário do Conselho Ultramarino, quando do desejo das Câmaras Municipais de Minas Gerais em criar um centro de formação de médicos (apud VENANCIO FILHO, 1982, p.7):

que poderá ser questão política se convinham estas aulas de arte e ciências em colônias... que podia relaxar a dependência que as colônias deveriam ter do Reino; que um dos mais fortes vínculos que sustentava a dependência das nossas colônias era a necessidade de vir estudar a Portugal; que este vínculo não se devia relaxar; que (o precedente) poderia talvez, com alguma conjuntura para o futuro, facilitar o estabelecimento de alguma aula de jurisprudência até chegar ao ponto de cortar este vínculo de dependência. (p.7). (grifos nossos)

Desde o Período Colonial, com os egressos da Faculdade de Direito de Coimbra, passando pelo Período Imperial, com as Faculdades de Direito de São Paulo e de Olinda/Recife, até a atualidade, os bacharéis de Direito desempenharam, e ainda desempenham, importante papel na vida nacional.

Lilia Moritz Schwarcz ${ }^{7}$, se referindo aos dois primeiros centros de estudos jurídicos do Estado Brasileiro, dirá que essas Academias Jurídicas formaram os políticos e homens de ciências do Brasil no Império e na Primeira República, os pensadores que decidiam a vida e os rumos do Estado nacional. 0 diploma em Direito e as profissão jurídicas passaram a ser cobiçados, pois, o bacharel tornava-se um intelectual da sociedade local. Análise, ainda que perfunctória, dos periódicos acadêmicos dessas duas Faculdades de Direito, leva-nos a ter noção da força que possuíam os juristas, pois era através desses periódicos e também das revistas, que os homens de sciencia legitimavam o seu saber e esbanjavam sua vasta cultura perante tanto a comunidade acadêmica, quanto também aos demais seguimentos letrados da sociedade.

\footnotetext{
${ }^{6}$ LACOMBE, Américo. “A Cultura Jurídica”. In: História Geral da Civilização Brasileira, Direção de Sérgio Buarque de Holanda.

70 espetáculo das raças. Cientistas, instituições e pensamento racial no Brasil: 1870-1930 Companhia das Letras, 1993.
} 
É o que levou à autora a afirmar que são os bacharéis de Direito “os eleitos da nação"!

Acerca do imaginário popular brasileiro, no século XIX, o viajante francês Adèle Toussaint-Samson acusa: “Não se admite no Brasil outras profissões além de médico, advogado ou negociante de grosso trato".

Gladston Mamede (2013, p. 19) ${ }^{8}$, com forte em Edson Alvisi Neves ${ }^{9}$, referindo-se à estrutura judiciária mercantil criada pelo então moderno Código Comercial brasileiro de 1850 (Lei 556) - modelo híbrido chancelado por Napoleão Bonaparte, que era composto não só por bacharéis, mas também por comerciantes - , aponta para uma disputa havida entre negociantes e bacharéis (poder econômico versus poder burocrático), ao final vencida por esses últimos, com a extinção do Tribunal do Comércio, em 1875. Idêntica disputa se repetiu, inclusive, entre juízes de paz (leigos) e juízes togados (bacharéis), novamente vencida pelos diplomados. Com efeito, os bacharéis em Direito desempenharam, tanto no Estado português, quanto no Estado brasileiro, a importante função de dar sustentação do poder, estruturando o aparato burocrático que dá base ao Direito racional, no qual funções permanentes (organizacionais) são exercidas conforme normas positivadas e por meio de órgãos de autoridade que se estruturam em cadeia hierárquica, com competências definidas. Os bacharéis predominavam na estrutura estatal e viabilizavam as ações estatais, sendo que sua importância facilmente se demonstra pela preocupação com a criação de cursos jurídicos no Brasil (MAMEDE, 2013, p. 19).

A notória presença, quando não predominância, dos bacharéis em Direito no primeiro século e meio do Brasil independente e soberano, é realidade inconteste. KOZIMA (1996, p. 241), em verdade, doutrina que:

A prática [o bacharelismo] consolidou-se de forma particularmente interessante no segundo reinado, o reinado dos bacharéis, na feliz expressão do prestigioso sociólogo [Gilberto Freyre], para quem 'ninguém foi mais bacharel nem mais doutor neste País que Dom Pedro II' (...) Durante o seu reinado, iniciado quando ainda menino, [Dom Pedro II] cercou-se de bacharéis moços, que renovavam-se nos gabinetes, na condução dos negócios do Estado, sob sua proteção e vontade. (p. 241).

\footnotetext{
${ }^{8}$ MAMEDE, Gladston. Direito empresarial brasileiro: empresa e atuação empresarial. Volume 1, 7 ed., São Paulo: Atlas, 2013.

${ }^{9}$ NEVES, Edson Alvisi. Magistrados e negociantes na corte do Império do Brasil: o Tribunal do Comércio. Rio de Janeiro: Faperj, 2008.
} 
Sobre o processo histórico que permitiu à origem, à existência e à permanência desse fenômeno social que é o bacharelismo, será José Murilo De Carvalho ${ }^{10}$, seguido de Alberto Venâncio Filho, quem melhor exporá seus motivos.

Carvalho (2008) demonstra, inclusive, o processo histórico que permitiu a substituição do predomínio do magistrado, egresso de Coimbra, pelo bacharel em Direito ou advogado (profissional liberal), formado pelas academias jurídicas brasileiras, notadamente a de São Paulo, como principal componente da Elite Política do Brasil oitocentista, agora já a partir da segunda metade do século XIX.

Para se entender a representatividade dos bacharéis na vida política imperial, Venâncio Filho (1982, p.14) diz que, sobre a época da Constituinte do Império:

dos noventa constituintes, oitenta e um tinham pelo menos a presunção de alguma cultura, pois vinte e três eram formados em direito; sete em cânones; vinte e dois eram desembargadores; dezenove eram clérigos, sendo um bispo; três médicos; sete militares, dos quais três marechais. (p. 14).

Interessante é notar que, embora as primeiras Faculdades de Direito só surgiram no Brasil por meio da Lei Imperial de 11 de Agosto de 1827 (que criou as faculdades de Direito de: São Paulo - atual Faculdade de Direito do Largo de São Francisco, da Universidade de São Paulo USP; e Olinda - que, em 1854, fora transferida para Recife: atual Faculdade de Direito do Recife, da Universidade Federal de Pernambuco - UFPE), portanto quase meia-década após a Constituinte, inda assim notória já era a presença do bacharel em Direito, egresso de Coimbra, no cenário político brasileiro. Assim, para se estudar Bacharelado (equivalente à atual Licenciatura portuguesa) em "Leis" (ou "Direito", quer Civil, quer Canônico; ou, ainda, "Ciências Jurídicas e Sociais"), os brasileiros tinham de ir à Faculdade de Direito da Universidade de Coimbra, na Metrópole, no outro lado do Atlântico Norte - o que, inegavelmente, em muito dificultava o acesso do nacional ao ensino superior, notadamente o jurídico. ${ }^{11}$

\footnotetext{
${ }^{10}$ CARVALHO, José Murilo de. A construção da ordem: a elite política imperial. $4^{a}$ ed. Rio de Janeiro: Civilização Brasileira, 2008.

${ }^{11} \mathrm{Na}$ Faculdade de Direito da Universidade de Coimbra, formaram-se: no século XVI, 13 brasileiros; já no século XVII, 354 estudantes brasileiros; no XVIII, o número subiu para 1752; do ano de 1781 ao de 1822 , ano da independência do Brasil, estudaram 339 brasileiros (VENANCIO FILHO, 1982, p.8).
} 
Nada obstante, pode-se notar que, dos 90 constituintes, 81 gozavam de alguma presunção de cultura, dados seus estudos invulgares; e destes, 45 tinham o grau de bacharel em Direito; isto é, $50 \%$ dos constituintes (e quase $60 \%$ dos constituintes letrados) era de bacharéis em Direito.

\section{Ainda para Kozima,}

A exemplo de outros países, também no Brasil, os bacharéis de Direito tiveram papel fundamental na estruturação do Estado, ocupando os mais importantes cargos públicos e espraiando-se por todos os poderes, seja no Império, seja na República. De fato, à exceção, talvez, de alguns revezamentos com a aristocracia de farda, os bacharéis, guiados pelos ideais da Revolução Francesa, estiveram metidos em praticamente todos os grandes acontecimentos políticos da história brasileira.

Para Pádua Fernandes ${ }^{12}$ (citando SÉRGIO ADORNO), a criação dos cursos jurídicos no Brasil visou atender às necessidades de "constituir quadros para o aparelho governamental" e de controlar "o processo de formação ideológica dos intelectuais a serem requisitados pela burocracia estatal", segundo Sérgio Adorno ${ }^{13}$; essa formação acadêmica reproduziu, pois, “as inconsistências do liberalismo brasileiro"14.

Além dos aspectos políticos, estavam metidos, também, os bacharéis: nas artes, nas ciências, na literatura ${ }^{15}$, na música, no jornalismo, no teatro, etc.

Ao que se pode depreender acentuado hibridismo na formação jurídica, fruto de um ensino jurídico livre, que valorizava atividades políticas, jornalísticas e literárias, dentre outras.

Há, no entanto, grande leva de autores que diferenciam as formações jurídicas proporcionadas pelas escolas de Olinda/Recife e de São Paulo. Para os quais, na academia pernambucana, priorizava-se o fenômeno jurídico a partir de uma pluralidade temática, reforçada por leituras naturalistas, biologistas, cientificistas, históricas e sociológicas,

\footnotetext{
12 Doutor em Direito pela Universidade de São Paulo. Autor de: Machado de Assis e o olhar irônico no país dos bacharéis. In: Revista Ética e Filosofia Política - № 14 - Volume 2 - Outubro de 2011.

13 ADORNO, Sérgio. Os aprendizes do poder: o bacharelismo liberal na política brasileira. Rio de Janeiro: Paz e Terra, 1988, p. 88.

${ }^{14}$ ADORNO, Sérgio. Op. Cit., p. 162.

15 "A Academia Brasileira de Letras (da qual Machado de Assis foi fundador e primeiro presidente, até sua morte, em 1908), é formada por muitas pessoas que estudaram Direito. Dos fundadores, 21 tinham estudado. E dos 'atuais' (época em que o artigo foi escrito, isto é, primeiro semestre de 2012) imortais, 20 são bacharéis em Direito. Além disso, Machado de Assis escolheu como patrono da Cadeira que iria ocupar um bacharel em Direito, José de Alencar". In: http://www.nosrevista.com.br/ acessado em $07 / 04 / 2012$, às $15 \mathrm{~h} 58 \mathrm{~min}$.
} 
apoiando-se fortemente num somatório de tendências que resultavam basicamente no evolucionismo e no monismo, sem desconsiderar a crítica sistemática a certas formulações jusnaturalistas e espiritualistas (WOLKMER, 1998, p. 82-83) ${ }^{16}$ : a Faculdade de Direito do norte produziu, com efeito, doutrinadores vigorosos - como as insuspeitas presenças de Tobias Barreto e de Silvio Romero na cultura brasileira (ADORNO 1988, p.121) ${ }^{17}$.

A Academia do norte nunca deixou, no entanto, de se ater às questões literárias: prova disso foi a primazia da Escola de Recife nos gêneros literários: 1) crítica e história literária e 2) historiografia, por ela introduzidos. Sobre a Crítica e História Literária, LEME, SERRA \& PINHO (1981) lecionam:

Na década de 70, a crítica conquista um importante papel no campo literário. É um dos gêneros responsáveis pela implantação do Realismo em nossa terra, surgindo com a Escola de Recife, liderada por Tobias Barreto. Lançado o alicerce, perde, a partir desse período, o caráter empírico para assumir aspecto científico e sociológico. 0 movimento é constituído por Sílvio Romero, Araripe Júnior e José Veríssimo, os maiores críticos e historiadores dessa geração. Posteriormente, aparecem João Ribeiro, Oliveira Lima e Joaquim Nabuco. ${ }^{18}$

Muita da formação ideológica ensinada na Faculdade de Direito do Recife foi, assim, transpassada para a crítica e história literária. E, da mesma forma, aconteceu com o gênero Historiografia. Senão vejamos:

O Positivismo atinge, também, o domínio da historiografia. Lançado por Varnhagen no período anterior, este gênero toma outros rumos na época realista, assumindo o caráter científico e revolucionário da mentalidade implantada pela Escola de Recife. ${ }^{19}$

Já a academia paulista, trilhou na direção da reflexão e da militância política, no jornalismo e na ilustração artística e literária. A faculdade de direito tornou-se um dos centros privilegiados da formação dos intelectuais destinados à cooptação pela burocracia estatal (WOLKMER, 1998, p. 83). Embora não tenha produzido tantos doutrinadores vigorosos, como a academia "rival" do norte, a Faculdade de Direito do sul teria propiciado, em contrapartida,

${ }^{16}$ WOLKMER, Antonio Carlos. História do direito no Brasil. Rio de Janeiro: Forense, 1998.

17 ADORNO, Sergio. Os aprendizes do poder: o bacharelismo liberal na política brasileira. Rio de Janeiro: Paz e Terra, 1988.

${ }_{18}$ LEME, Odilon Soares; SERRA, Stella Maria Garrafa; e PINHO, José Albertoni de. Assim se escreve... Gramática - Assim escreveram... Literatura: Brasil - Portugal. São Paulo: EPU, 1981, p. 375-376.

19 LEME, Odilon Soares; SERRA, Stella Maria Garrafa; e PINHO, José Albertoni de. Assim se escreve... Gramática - Assim escreveram... Literatura: Brasil - Portugal. São Paulo: EPU, 1981, p. 376. 
uma safra também insuspeitável de ministros, conselheiros de Estado, deputados, senadores, presidentes de província, juízes de notoriedade nacional e, salvo raras exceções, doutrinadores jurídicos (ADORNO 1988, p.121).

Luiz Carlos Cancellier De Olivo ${ }^{20}$ aponta que a formação profissional do bacharel não se deu a partir da sala de aula, mas no ambiente extraclasse, ou seja, nos grêmios estudantis, nas sociedades literárias, nos clubes. Era neste ambiente que os estudantes solidificavam a ideologia prática do liberalismo e aprendiam que "o segredo da harmonia na vida civil e política residia na descoberta de pontos de equilíbrio entre radicalismos contrapostos, entre os avanços da história e a precaução", qualidade esta dos "espíritos práticos e reflexivos”, ou seja, dos próprios bacharéis (ADORNO, 1988, p. 158).

Yury Vieira Tupynambá De Lélis Mendes $^{21}$, nesse mesmo sentido, ao se referir ao ensino jurídico brasileiro oitocentista, nestes termos alude:

O ensino jurídico brasileiro, desde os seus primórdios, sempre teve como característica certo hibridismo, que só veio a se intensificar com as reformas educacionais que implantaram o ensino livre no âmbito do estudo do direito, em meados do século XIX. Foi nesse contexto, que floresceram, ao longo dos anos, as diversas entidades estudantis - desde sociedades secretas, passando por grupos políticos e jornais acadêmicos, até entidades literárias e culturais -, no bojo das faculdades de Direito.

Coube à imprensa acadêmica um papel relevante nesta função pedagógica, pois ela estabeleceu os contornos daquilo que viria a ser o protótipo do bacharel juridicista formado em São Paulo no século XIX: saber ornamental, culto à erudição linguística, cultivo ao intelectualismo, identificação com a cultura europeia - inglesa, francesa ou alemã, fé na razão, uso da retórica e do proselitismo, formalismo no comportamento. Ser estudante de direito, antes de tudo, era ter uma atividade no jornalismo, produzir literatura, participar de alguma loja maçônica ou de clube estudantil (OLIVO, 2011, p.36).

A título de curiosidade, cabe destaque o que diz ARMANDO SOARES DE CASTRO FORMIGA22: "O Periodismo Jurídico no Brasil emergiu a partir de 1843 e atuou como importante

${ }^{20}$ OLIVO, Luis Carlos Cancellier de. Por uma compreensão jurídica de Machado de Assis - Florianópolis: Ed. da UFSC: Fundação Boiteux, 2011. p.36.

${ }^{21}$ MENDES, Yury Vieira Tupynambá de Lélis. [Orelha]. In: MAGALHÃES, Anala Lélis; MENDES, Yury Vieira Tupynambá de Lélis (Orgs.). Antologia Jubileu de Ouro da Unimontes: prosas \& versos. São Paulo: Catrumano, 2012. 
elo no florescer da cultura jurídica oitocentista. Os jornais e revistas jurídicos se desenvolveram de diversas formas, em especial, na órbita das Academias de Direito".

\section{PERSONAGENS MACHADIANOS E BACHARELISMO: UMA ANÁLISE}

A História e a Literatura se correlacionam intimamente. Não raras vezes, um desses campos do conhecimento serve de fonte ao outro: a História, na investigação científica como busca pela verdade fática, pode lançar mão de textos literários como fonte histórica (tal como pode acontecer com a Bíblia, p. ex.; e tal qual hemos de fazer, no presente trabalho, com a obra machadiana); e a Literatura (o "escrever artístico"), sempre sôfrega por novas criações artístico-literárias, pode se basear em episódios históricos que, escritos sob a égide da pena de um escritor, pode vir a se imortalizar de maneira que nem o historiador, em seu árduo e exaustivo ofício, conseguiria fazê-lo. Nesse caso, vemos os episódios históricos como fonte literária (é o caso, por exemplo, do Idílio de Pórcia e Leolino, episódio ocorrido no sertão baiano na primeira metade do século XIX e que foi, por consagrados autores, imortalizado em valiosas obras literárias).

Para o jus-historiador argentino RICARDO DAVID RABINOVICH-BERKMAN (2011) ${ }^{23}$, professor da Facultad de Derecho da Universidad de Buenos Aires, "a reconstrução ideal do historiador é considerada científica quando se nutre na busca, ordenamento e estudo crítico dos testemunhos" (p. 33), devendo ser científica a tarefa de quem se dedica à história como ciência: Ou seja, "nem artística, nem literária. Estaria aqui a diferença entre a ciência historiográfica e um 'parente próximo': a literatura histórica de ficção” (RABINOVICH-BERKMAN, 2011, p. 33). Destaca, desta última, alguns subgêneros, como o conto, o romance e a obra de teatro. Disse, ainda, que o romance histórico é mais antigo que a história científica, sendo que hoje o gênero do romance histórico, muito desenvolvido nos séculos XIX e XX (nos quais viveu e se insere Joaquim Maria Machado de Assis), é um dos ramos mais exitosos da literatura (RABINOVICHBERKMAN, 2011, p. 33-34)

\footnotetext{
22 FORMIGA, Armando Soares de Castro. O periodismo jurídico oitocentista na órbita das academias brasileiras. In: Revista Integralização Universitária - v.1, n.1 - Abril/Setembro de 2007, Palmas (Tocantins): Provisão Gráfica e Editora Ltda, p. 105-116.

${ }^{23}$ RABINOVICH-BERKMAN, Ricardo David. Trilhas abertas na História do Direito: conceitos, metodologia, problemas e desafios. Rio de Janeiro: Lumen Juris, 2011.
} 
Essa expressões literárias artísticas, quando estão baseadas em fontes tratadas com algo de crítica, ajudam muito na difusão e compreensão do passado. Em geral, porém, sua finalidade não é o conhecimento da verdade fática, mas a criação da beleza ou a transmissão de idéias e efeitos. Ou simplesmente a satisfação artística de criar. Tais fronteiras, contudo, são sempre indefinidas. (RABINOVICH-BERKMAN, 2011, p. 35).

Machado de Assis, com efeito, lançou mão da escrita de textos literários sob os três aludidos subgêneros da literatura histórica de ficção (considerando que o homem e sua produção são contextualizadamente produtos histórico-sociais).

Luiz Carlos Cancellier De Olivo (2011, p.27), após elucidar a escolha do "Bruxo da Cosme Velho", em dois dos seus principais romances, por advogados como narradores (Brás, coimbrão; Bento, san-franciscano), indaga se "Poderia Machado ter optado por narradores que tivessem formação intelectual e profissional diferentes e, mesmo assim, chegado às mesmas conclusões?". E prossegue, o autor, inquirindo "Se Brás fosse um médico e Bento um engenheiro, a narrativa seria a mesma, o desenvolvimento da ação seguiria a sequência por nós conhecida?".

A seguir, admite não parecer ser aleatória esta escolha, "principalmente ser for levado em conta que, quando se trata dos contos, em praticamente metade deles a figura do operador jurídico aparece como personagem, principal ou secundário, narrador ou não”.

Ou seja, Machado de Assis é todo Direito - em sua vida de funcionário público sobram exemplos de atuação jurídica; em suas amizades sobressaem os bacharéis; seus personagens jurídicos têm grande destaque (impressionante destaque); e a linguagem jurídica aparece em todos os recantos da vasta obra machadiana. (Cássio Schubsky \& Miguel Matos) ${ }^{24}$.

A citação acima transcreve o posicionamento "associativista” dos autores SCHUBSKY \& MATOS $^{25}$ em relação ao "Direiticismo" entre a vida e obra machadianas.

$\mathrm{Na}$ obra machadiana, aproximadamente cem personagens são ligados ao Direito, dentre outros, encontra-se: estudantes de Direito, bacharéis, jornalistas, professores, políticos, advogados, escrivães, oficiais de fóruns e de cartórios, procuradores, juízes, desembargadores e diplomatas.

\footnotetext{
${ }^{24}$ In: http://www. nosrevista.com.br/ acessado em 07/04/2012, às 15h58min.

${ }^{25}$ Vide: MATOS, Miguel; SCHUBSKY, Cássio. Doutor Machado - o direito na vida e na obra de Machado de Assis. São Paulo (SP): Lettera.doc, 2008, 376p.
} 
Tais personagens, evidente, não são descritos por Machado com um padrão uniforme de comportamento. Não se constituem como tipos ideais, fechados e monolíticos. Há, em cada situação, uma possibilidade variada de desfecho, sem que, no entanto, os limites e as possibilidades sejam inverossímeis. (OLIVO, 2011, p. 27)

Para Santiago (1996, p. 34) apud Olivo (2011, p.27-28), somente um advogado experiente nas lides forenses poderia atuar como defensor de Bentinho e redigir uma peça de oratória na qual ficasse devidamente comprovado que o ex-seminarista de mata-cavalos agiu não por vingança, mas pura e simplesmente em defesa da honra.

Ainda Olivo (2011, p.28):

Da mesma forma, era condição para que a narrativa memorialística do defuntoautor se tornasse plausível que ela fosse contada por um personagem ilustrado, com formação jurídica liberal, típico representante das classes produtoras agrárias. Só assim seria possível entender a volubilidade de Brás, o seu comportamento perante a coxa-flor da moita Eugênia ou a defesa acusatória que faz do cunhado Coltrim, que como salienta Schwarz (2001, p. 119), está marcada por desculpas que inculpam, atenuantes que agravam, enfim, "uma defesa que, na verdade, é uma denúncia do acusado".

A escolha da profissão do narrador, tanto nos dois romances quanto nas dezenas de contos de nosso maior imortal, sugere que ela é impositiva, que faz parte da própria estrutura do texto, como condição de sua existência e desenvolvimento (OLIVO, 2011, p.28).

São palavras do professor Luís Carlos Cancellier De Olivo (2011, p.28), que leciona:

Admitindo a hipótese, justifica-se a existência de uma relação mimética e histórica entre a realidade extraliterária e o texto ficcional, que assim ultrapassa a condição de mero relato histórico, jornalístico ou sociológico e ganha o estatuto de genuína obra literária. É o fenômeno que Candido (1993) chama de redução estrutural.

Gledson (1991, p. 13) descreve o método de veicular situações políticas no texto literário como alegórico, à medida que requer do leitor a observância de paralelos entre o âmbito privado e a história política. A questão então é de se perguntar: qual a alegoria dos bacharéis em direito nos textos machadianos?

Neste tópico, iremos analisar algumas dessas personagens da vasta obra de Machado de Assis, tanto de sua primeira fase (entendida pela crítica literária como fase romântica machadiana ou fase de preparação, que vai de seus primeiros escritos em versos, em 1855, até a 
publicação de laiá Garcia, em 1878) quanto de sua segunda fase (entendida pela crítica como o início do realismo na Literatura Brasileira; portanto, a fase realista machadiana ou fase de maturidade intelectual ${ }^{26}$, inaugurada pela obra Memórias Póstumas de Brás Cubas, publicada no ano de 1881, e que vai até à publicação de Memorial de Aires, em 1908, também ano de sua morte), identificando a presença do Bacharel em Direito na obra do "Bruxo da Cosme Velho", epíteto pelo qual é conhecido o autor Joaquim Maria Machado de Assis (1839-1908).

Cabe, porém, antes disso, acrescentar alguns prolegômenos biográficos sobre nosso maior imortal: Joaquim Maria Machado de Assis nasceu no Morro do Livramento, no Rio de Janeiro, em 1839. De origem modesta, mestiço, começou a ganhar a vida como aprendiz de tipógrafo. Tendo sido sempre um autodidata, estreou na revista "Marmota Fluminense", publicando seu primeiro trabalho em 1855: a poesia “Ela". Daí tornou-se revisor (editora Paula Brito) e depois crítico literário (Marmota). Em 1869 casou-se com D. Carolina Xavier de Novaes, de quem se tornaria viúvo em 1904, ocasião em que escreveria o célebre soneto "A Carolina”, e a partir de quando viveria a tristeza da viuvez, até seu falecimento, quatro anos depois, em sua residência, no Cosme Velho, em 1908. Foi um dos fundadores e o primeiro presidente da Academia Brasileira de Letras ( $\mathrm{ABL}$ ), desde 20 de junho de 1897 até sua morte, tendo deixado profusa obra, até hoje reverenciada pelos literatos brasileiros e estrangeiros e que, certamente, atravessará os séculos na estante literária da eternidade.

\subsection{Romances: Primeira Fase}

Desde seus primeiros romances, em sua primeira "fase" (época em que Machado de Assis está preso aos valores do Romantismo, onde tanto sua ficção como os demais gêneros revestem-se de aspectos sentimentais, porém sem exageros) ${ }^{27}$, a obra machadiana já era imbuída de conotação à personagem bacharelesca - “o protótipo de figurão que marcará sua fase madura"28.

Em A Mão e a Luva, os amigos Estevão e Luís Alves formaram-se pela tradicional Faculdade de Direito do Largo de São Francisco - a Academia de São Paulo. Estevão, após

\footnotetext{
${ }^{26}$ LEME, Odilon Soares; SERRA, Stella Maria Garrafa; e PINHO, José Albertoni de. Assim se escreve... Gramática - Assim escreveram... Literatura: Brasil - Portugal. São Paulo: EPU, 1981.

${ }^{27}$ LEME, Odilon Soares; SERRA, Stella Maria Garrafa; e PINHO, José Albertoni de. Assim se escreve... Gramática - Assim escreveram... Literatura: Brasil - Portugal. São Paulo: EPU, 1981, p. 358.

${ }^{28}$ ARAÚJO, Laíse Helena Barbosa. Op. Cit., p.57.
} 
formado, torna-se à Corte: com os mesmos sonhos, e a mesma simpleza de coração, conforme aponta LAÍSE ARAÚJO. “Embora [Estevão] ${ }^{29}$ tenha feito estudos em Direito, apenas 'prezava' a Ciência Jurídica. Suas preferências intelectuais misturavam Política à Literatura" 30 . Naturalmente, por óbvio, possuía aspirações políticas; entretanto, faltava-lhe um patrocinador, já que nascera "pobre”, e sustentava-se com recursos provindos do seu ofício de advogado, “sempre subsidiários aos verdadeiros anseios do jovem bacharel” (ARAÚJO, 2008, p. 58).

Já em Helena, o Dr. Matos, para compensar a (quase) ignorância da Ciência do Direito, possuía "noções muito aproveitáveis de meteorologia e botânica, da arte de comer, do voltarete, do gamão e da política” (ASSIS, 1962a: p. 285).

Acerca de seus traços característicos, três dos mais destes, aponta ARAÚJO, no bacharel do século XIX, são: o ócio, a superficialidade, e a posição social.

A ociosidade, já temia Dona Valéria, mãe de Jorge, protagonista de laiá Garcia, que "viesse em seu filho fazer-se natureza" (ARAÚJO). Em tom crítico, Machado de Assis demonstra ser Jorge "abonado, possuidor de muitas rendas" - "o que pode assegurar-lhe viver à farta" (ARAÚJO) -, mas que, outrossim aos demais citados, usava do Direito não por paixão e vocação: mas apenas como forma de ter seu nome cravado ao Almanaque Laemmert - consoante, ainda, ao que preleciona ARAÚJO.

\subsection{Romances Maduros}

$\mathrm{Na}$ segunda fase machadiana (época em que seu estilo amadurece e o autor inaugura a escola Realista, transferindo a ação de seus romances para o mundo interior dos personagens, com sua obra penetrando nos domínios da alma humana, utilizando-se do humorismo como válvula de escape, que ameniza o caráter cético e pessimista em que se alicerçou seu espírito de homem infeliz e desgostoso da vida) ${ }^{31}$, há, além do rico Brás Cubas ${ }^{32}$, que deseja tornar-se Ministro de Estado, e seu oponente-mor, Lobo Neves ${ }^{33}$ (que casou-se com o grande amor

${ }^{29}$ Grifos nossos.

${ }^{30}$ ARAÚJO, Laíse Helena Barbosa. Op. Cit., p.58.

${ }^{31}$ LEME, Odilon Soares; SERRA, Stella Maria Garrafa; e PINHO, José Albertoni de. Assim se escreve... Gramática - Assim escreveram... Literatura: Brasil - Portugal. São Paulo: EPU, 1981, p. 358.

${ }^{32}$ Advogado formado pela Faculdade de Direito da Universidade de Coimbra; Brás Cubas, chega a eleger-se Deputado, mas não consegue fazer-se Ministro de Estado.

${ }^{33}$ ASSIS, Machado de. Memórias Póstumas de Brás Cubas. São Paulo (SP): Escala Educacional, 2008. 
daquele), que é bem sucedido na Política (tendo sido, inclusive, Presidente de Província): Camacho $^{34}$ - que quer voltar para a Política -, e Batista ${ }^{35}$ - que tem um “comichão" por ela.

Natividade, ao sonhar com um "grandioso futuro para seus gêmeos", não pensa senão em "providenciar um diploma de Direito para um deles" (in casu, Paulo). Em todos esses casos (supracitados), há a relação direta entre Direito e Política.

Em Dom Casmurro, Bentinho ${ }^{36}$ abraça a formação jurídica como subterfúgio à vida religiosa. Ele, ao contrário do estereótipo de bacharel de Direito, não se interessa por questões políticas, econômicas, ou sociais; era, ademais, um relativista. Seu tio, Cosme ${ }^{37}$, advogado criminalista, não enriquecia no Fórum, mas "ia comendo"38.

Ou seja, "tio Cosme”, como qualquer outra personagem em questão, não obteve êxito na advocacia: assim, pode-se elucidar que o fracasso profissional seja outra marca das personagens machadianas. ${ }^{39}$

Teófilo, de Quincas Borba, foge a essa “regra”, por ser mais aplicado e dado às seriedades: entretanto, talvez por isso mesmo - por não ser possuidor da amoralidade necessária -, termina seus dias no ostracismo político.

Já o bel. Conselheiro Aires, narrador de Memorial de Aires ${ }^{40}$ e Esaú e Jacó, deu-se à diplomacia. Ainda no Memorial de Aires, pode-se notar, também, a presença de um outro bacharel: o Desembargador Campos - tio da jovem Fidélia, filha do Barão de Santa Pia.

Embora não se trate de um romance, comentando sobre o conto "Primas de Sapucaia!" (ASSIS, 1997b, p. 422), acusa OLIVO (2011, p.35), dizendo: no diálogo entre o bacharel, sobrinho

\footnotetext{
${ }^{34}$ ASSIS, Machado de. Quincas Borba. São Paulo (SP): Escala Educacional, 2008.

${ }^{35}$ ASSIS, Machado de. Esaú e Jacó. São Paulo (SP): Escala Educacional, 2008. (Batista é um "típico político fisiológico que muda de partido como quem troca de camisa, sem ter qualquer convicção política ou ideológica". In: http: //www.sosestudante.com/).

36 "personagem central da obra, era advogado militante, formado na Faculdade de Direito do Largo de São Francisco", In: http://www.nosrevista.com.br/

${ }^{37}$ ASSIS, Machado de. Dom Casmurro. São Paulo (SP): Escala Educacional, 2008.

${ }^{38}$ ASSIS, Machado de. Op. Cit., p. 20.

39 "Em geral, Machado de Assis coloca maus advogados em suas obras. Ironiza-os. Na maioria das vezes, o diploma é apenas uma relíquia. Fica guardado e nunca é usado. Bentinho é uma das poucas exceções. Era um bom advogado". Muito embora, "alguns personagens realmente exerciam a profissão jurídica na obra. Machado descreve com riqueza de detalhes a atuação jurídica de alguns. Bentinho, por exemplo, chega até a discutir estratégias jurídicas em 'Dom Casmurro'”. In: http://www.nosrevista.com.br/

${ }^{40}$ ASSIS, Machado de. Memorial de Aires. São Paulo (SP): Escala Educacional, 2008.
} 
do proprietário de terras José Ribeiro, e o promotor em Minas Gerais, Oliveira, as reminiscências dos estudos na faculdade de direito de São Paulo surgem quando os dois estão desolados, por questões de amores: “Hás de lembrar-te dos nossos planos da academia, quando nos propúnhamos, tu a ministro do império, eu da justiça”, diz o sobrinho, tentando animar o antigo colega.

O Direito era, sem dúvida, a porta de acesso à Elite local. É o que se observa nos discursos e aconselhamentos de Bento Cubas ao filho, Brás Cubas; nas intenções de Natividade, para um de seus filhos, o gêmeo Paulo; e, no conto Teoria do Medalhão ${ }^{41}$, nos dizeres e indicações de um pai a Janjão, seu jovem filho bacharel ${ }^{42}$ : “a predestinação à vida pública e o Direito entrelaçam-se como etapa estratégica nessa inserção, já que o principal projeto da elite brasileira era a vida pública, carreira vinculada principalmente ao Direito, curso forjado para melhor preparar o futuro deputado ou senador" (ARAÚJO, 2008, p. 61).

\section{CONCLUSÃO}

Ao longo deste trabalho, procurou-se demonstrar, através de epítomes dimensões, que, tanto na vida quanto na obra machadianas, a personagem e o fenômeno bacharelísticos fazem-se presentes.

Outrossim, pôde-se depreender o olhar lançado por Machado de Assis à sociedade da época, por meio de sua obra; bem como a crítica ao retoricismo, utilizando-se da própria retórica, tal como o fez Manoel Bonfim (apud CARVALHO).

Fez-se, por derradeiro, uma análise "aspectológica" de personagens, e depreendeu-se a crítica, por meio de sarcasmos e ironias, ao "bacharel de Direito" da época, que embora símbolo-mor do status político nos idos imperiais, fora tratado como um "fracassado", ou pelo menos um "protótipo", não necessariamente bem-sucedido, de um “medalhão” referencial (que, como seu discurso verborrágico, vivia as superficialidades ocas e vazias de um anseio, sôfrego e intérmino, por status), na construção machadiana.

\footnotetext{
${ }^{41}$ ASSIS, Machado de. Papéis Avulsos. São Paulo (SP): Escala Educacional, 2008, p. 48-53.

42 OLIVO (2011, p.36): Em Teoria do medalhão (ASSIS, 1997b, p. 288), quando o jovem bacharel Janjão completa 21 anos, o pai ensina-lhe as regras de comportamento que assegurarão ao herdeiro um papel de destaque e sucesso na sociedade: "Vinte e um anos, algumas apólices, um diploma, podes entrar no parlamento, na magistratura, na imprensa, na lavoura, na indústria, no comércio, nas letras ou nas artes. Há infinitas carreiras diante de ti”.
} 
Ao que, novamente, cabe-nos dizer: a escolha da profissão de narradores e personagens, tanto nos dois principais romances quanto nas dezenas de contos de nosso maior imortal, sugere que ela é impositiva, que faz parte da própria estrutura do texto, como condição de sua existência e desenvolvimento (OLIVO, 2011, p.28).

\section{REFERÊNCIAS}

ADORNO, Sérgio. Os aprendizes do poder: o bacharelismo liberal na política brasileira. Rio de Janeiro: Paz e Terra, 1988.

ALMEIDA FILHO, José Carlos de Araújo. O Ensino Jurídico, a Elite dos Bacharéis e a Maçonaria do Séc. XIX. (Dissertação de Mestrado, Universidade Gama Filho, Rio de Janeiro-RJ, 2005).

ARAÚJO, Laíse Helena Barbosa. Bacharelismo e Retórica na Construção do Estado Brasileiro. In: Mnemosine Revista, vol. 1, $\mathrm{n}^{\circ}$ 01, jan./jun. 2010.

ARAÚJO, Laíse Helena Barbosa. O Medalhão do Século XIX: o bacharelismo em Machado de Assis. (Monografia, CESUPA, Belém-PA, 2008).

ASSIS, Machado de. Dom Casmurro. São Paulo (SP): Escala Educacional, 2008.

ASSIS, Machado de. Esaú e Jacó. São Paulo (SP): Escala Educacional, 2008.

ASSIS, Machado de. Memorial de Aires. São Paulo (SP): Escala Educacional, 2008.

ASSIS, Machado de. Memórias Póstumas de Brás Cubas. São Paulo (SP): Escala Educacional, 2008.

ASSIS, Machado de. Papéis Avulsos. São Paulo (SP): Escala Educacional, 2008.

ASSIS, Machado de. Quincas Borba. São Paulo (SP): Escala Educacional, 2008.

BONAVIDES, Paulo. Teoria do Estado. São Paulo: Malheiros, 1995.

CARVALHO, José Murilo de. A construção da ordem: a elite política imperial. $4^{\mathrm{a}}$ ed. Rio de Janeiro: Civilização Brasileira, 2008.

CARVALHO, José Murilo de. Teatro de sombras: a política imperial. São Paulo: Edições Vértice, 1988.

CITAÇÕES E ALUSÕES NA OBRA DE MACHADO DE ASSIS. Disponível em

http://www.machadodeassis.net/. Acesso em 13 de março de 2012, às 15h30min. 
CRUZ, Breno de Paula Andrade; MARTINS, Paulo Emílio Matos. O poder do bacharel no espaço organizacional brasileiro: relendo Raízes do Brasil e Sobrados e mucambos. In: www.ebape.fgv.br/cadernosebape, Volume IV - Número 3 - Outubro 2006.

FERNANDES, Pádua. Machado de Assis e o olhar irônico no país dos bacharéis. Revista Ética e Filosofia Política - No 14 - Volume 2 - Outubro de 2011.

GONÇALVES, Marina Leite. Masculinidade e Elite Imperial Brasileira: uma reinterpretação das obras "Ressurreição", “A Mão e a Luva”, "Helena”, e "laiá Garcia”. (Dissertação de Mestrado, Universidade Estadual de Montes Claros, Montes Claros-MG, Março/2011).

KOZIMA, José Wanderley. Instituições, Retórica e o Bacharelismo no Brasil. In: WOLKMER, Antônio Carlos (Org.). Fundamentos de História do Direito. Belo Horizonte: Del Rey, 1996.

LEME, Odilon Soares; SERRA, Stella Maria Garrafa; e PINHO, José Albertoni de. Assim se escreve... Gramática - Assim escreveram... Literatura: Brasil - Portugal. São Paulo: EPU, 1981.

NEVES, Gilson Pereira. Machado de Assis e o Mito Antissemita: A genealogia como contraponto crítico ao estereótipo do judeu em Papéis avulsos. (Dissertação de Mestrado, Universidade Estadual de Montes Claros, Montes Claros-MG, Janeiro/2011).

PRADO, Daniel Nicory do. Aloysio de Carvalho Filho: pioneiro nos estudos sobre "Direito e Literatura" no Brasil? Artigo obtido pela Internete.

TUFANO, Douglas. Estudos de Língua e Literatura: volume 1. São Paulo: Moderna, 1977.

VENÂNCIO FILHO, Alberto. Das Arcadas ao bacharelismo: 150 anos de ensino jurídico no Brasil. São Paulo: Perspectiva, 1977.

VENÂNCIO FILHO, Alberto. Os Juristas. In:

http: //www.academia.org.br/abl/cgi/cgilua.exe/sys/start.htm?infoid=63\&sid=258, acessado em 13 de Março de 2012, às 15h30min.

Recebido em: 29.04.2014

Revisões em: 04.06.2014

Aprovado em: 03.07.2014 